\title{
Moral Hazard in a Mutual Health Insurance System: German Knappschaften, 1867-1914
}

\author{
TIMOTHY W. GUINNANE AND JOCHEN STREB
}

The Knappschaft was a mutual association through which German miners insured themselves against accident, illness, and old age. The Knappschaft underlies Bismarck's sickness and accident insurance legislation, and thus Germany's system today. This article focuses on moral hazard, which plagued the Knappschaften in the later nineteenth century. Sick pay made it attractive for miners to feign illness that made them unable to work. We outline the moral hazard problem the Knappschaften faced as well as the mechanisms they devised to control it, and then use econometric models to demonstrate that those mechanisms were at best imperfect.

$\mathrm{M}$ ost wealthy countries today face serious problems related to the way they insure their populations against the financial consequences of illness, accident, and old age. A central issue in the design of these social insurance schemes dogged them in the nineteenth century and remains critical today: how to target benefits to the program's intended beneficiaries. Many of the conditions or events against which policy intends to insure individuals are difficult or costly for others to observe. Without proper controls, generous benefits will both increase the welfare of the targeted population, as intended, and encourage others to claim they belong to the targeted population, wasting resources and perhaps reducing

The Journal of Economic History, Vol. 71, No. 1 (March 2011). (C) The Economic History Association. All rights reserved. doi:10.1017/S0022050711000039.

Timothy W. Guinnane is Philip Golden Bartlett Professor of Economic History, Department of Economics, Yale University, Box 208269, New Haven, CT 06520-8269. E-mail: timothy.guinnane@yale.edu. Jochen Streb is Professor of Economic History, Department of Economics, University of Hohenheim, Schloss, Speisemeistereiflügel, 70599 Stuttgart, Germany. E-mail: jochen.streb@uni-hohenheim.de.

This article is part of a larger project entitled, "Vergangenheit und Zukuft sozialer Sicherungssystem am Beispiel der Bundesknappschaften und ihrer Nachfolger," which was funded by the Leibnizgemeinschaft. A longer version available as a working paper (SSRN No. 1484753) reports additional background material and the text of some contemporary observations noted here. That version also reports the precise sources of our data. We thank Virginia Calkins and Tobias Jopp for excellent research assistance. Jopp is also part of the larger project; see Jopp (2010a, 2010b). Herb Emery, James Fenske, Manuel Frondel, Amanda Kowolski, Carolyn Moehling, John Murray, Christoph M. Schmidt, and Ebonya Washington provided excellent suggestions on an earlier version of the article. We also appreciate comments from seminar participants at the Rheinisch-Westfälisches Institute für Wirtschaftsforschung eV (RWI). We thank RWI for Nolan Ritter's research assistance, for additional funding, and for making our participation in this project possible. Our views are not necessarily those of RWI. The editor and three referees provided valuable comments on an earlier draft. 
political support for the program. This article focuses on a particular type of moral hazard: that caused by replacement pay for sick workers in elevating absenteeism.

Moral hazard of this form became an important question in the sickness and accident insurance system created in Germany in the late nineteenth century. This article focuses on the Knappschaften (or KV), the organizations through which German miners insure themselves against accident, illness, and old age. ${ }^{1}$ The Knappschaften's problems implied serious difficulties in extending the system to other classes of workers; miners had long identified themselves as a privileged group with their own ideas of honor and self-help, and if moral hazard undermined mutual insurance in this industry, then the entire idea was problematic. Germany's social insurance system operating today is based, indirectly, on the model pioneered by the Knappschaften. These organizations still exist, and although the industries in which they work have been in decline, a single all-German Knappschaft now open to all workers is still active. The Knappschaften had two distinctive features. First, the workers and firms in covered industries fund and run the organization themselves. Although they operate within constraints set down by the government, the Knappschaften tell us much about member preferences. Second, membership in the relevant Knappschaft was compulsory for anyone who worked in the covered industries. The Knappschaften allow us to study health insurance in a context where adverse selection is not possible. ${ }^{2}$

We focus here on a period of dramatic change, from the 1850s until World War I. The Knappschaften in this period faced an important question: how to transform often small, informal organizations into institutions that could meet the growing needs of their members,

\footnotetext{
${ }^{1}$ Knappschaft is singular, Knappschaften, plural. The German literature usually refers to these institutions as Knappschaftsverein, or "Knappschaft organization" (KV). We refer to the Knappschaft's members as "miners" as short-hand. About 70 percent of KV members were coal miners and another 20 percent were other types of miners. The rest worked in related activities, such as iron production. The Knappschaften had two distinct roles: they provided sickness and accident insurance as well as disability insurance for cases in which the workers were no longer able to work, and benefits to survivors. This article focuses on the sickness and accident insurance alone. The disability component is the subject of a future paper. For simplicity, we refer throughout to "sickness" when we mean "sickness and accidents."

${ }^{2}$ Since all workers must join their Knappschaft, the only adverse selection possible would be that associated with choice of occupation. Clearly the Knappschaft made mining and the other dangerous occupations more attractive than they would have been in the absence of the Knappschaft. It is theoretically possible, as well, that men would decide to become miners because for some reason they thought themselves more likely to become ill. We have never seen a suggestion to this effect in the literature. It seems unlikely; before a worker could become a full member of the Knappschaft, a doctor had to certify that the worker was healthy (provide a Gesundheitsattest).
} 


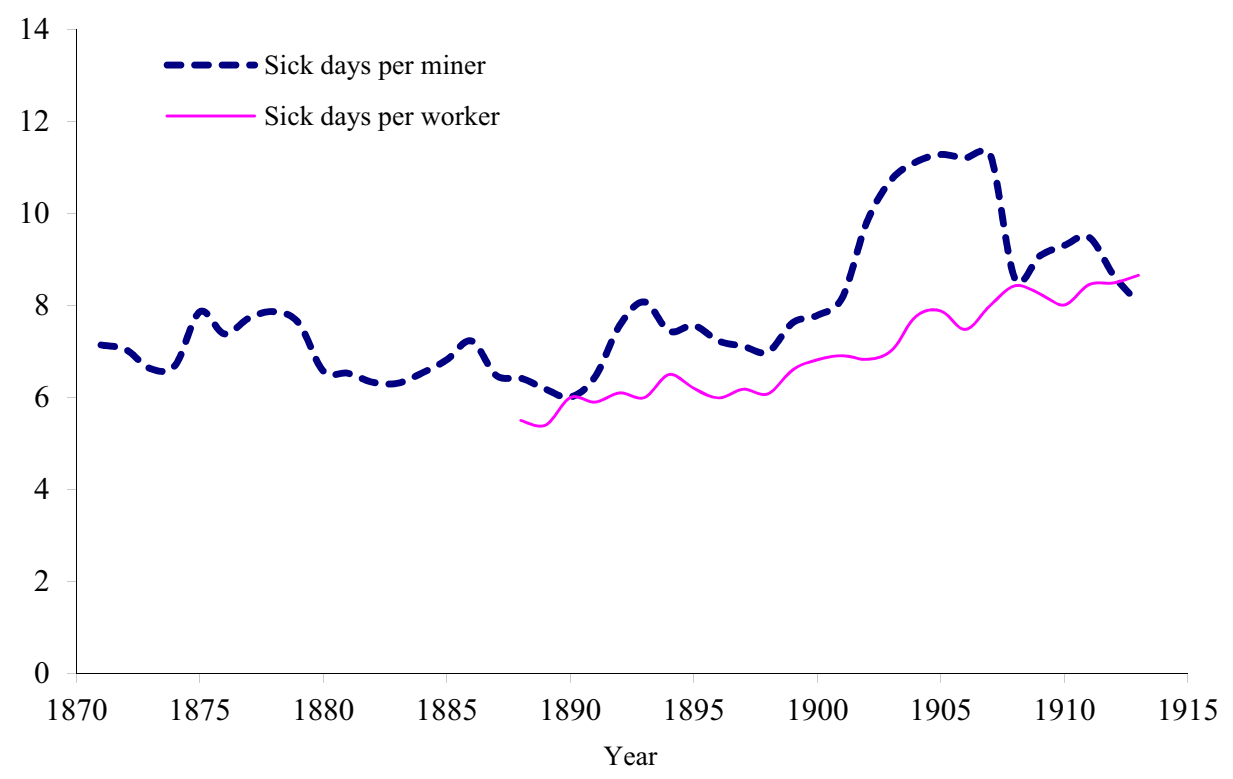

FIGURE 1

SICK DAYS PER MINER (PRUSSIAN KNAPPSCHAFTEN ONLY) 1861-1913 AND SICK DAYS PER WORKER IN THE IMPERIAL HEALTH INSURANCE SYSTEM (1888-1913)

Source: Statistik der Knappschaftvereine des preussischen Staates, Jahrgänge, 1861-1922; and Khoudour-Castéras, "Welfare State," p. 234.

without destroying the sense of solidarity that allowed the Knappschaften to provide a guaranteed safety net without being overwhelmed by moral hazard problems. Moral hazard was a serious issue in the eyes of contemporary observers; Dr. Isak Schlockow was not alone in viewing moral hazard as a serious threat to the entire mutual insurance approach. ${ }^{3}$ Simulation (feigning illness) and Verschleppung (pretending to be ill after cured) supposedly plagued nearly all Knappschaften. Figure 1 reports the average sick days lost in the Prussian Knappschaften and in the Imperial Health Insurance System set up by Bismarck. Until the late nineteenth century, the number of sick days per member in the Knappschaften as a whole varied between six and eight days, but with much larger annual variations in individual funds. At the end of the nineteenth century, we see the explosion of sick days that worried the contemporaries cited below. The broader health insurance system experienced a rather different pattern: sick days per covered worker grew steadily from the system's inception.

\footnotetext{
${ }^{3}$ See Schlockow, Gesundheitspflege, p. 126.
} 
This article uses the official reports of the KV to test for the existence and extent of moral hazard. Contemporaries stressed an important tradeoff. Larger Knappschaften were arguably better, ceteris paribus, than small. A larger institution could spread administrative overheads over more workers; could build and operate its own hospitals, with staff and facilities specialized for the problems facing their members; and a larger institution could better absorb the risk of unusual financial demands posed by a serious accident or outbreak of illness. Yet many claimed that the problem of moral hazard was worse in the larger Knappschaften. In a larger institution, workers were less likely to know each other personally and more likely to feel that in abusing the fund they are abusing an institution, rather than their friends' pocketbooks. A larger Knappschaft's members were typically also more geographically separated, because its mines and other works were spread out over a larger area. Such workers might be better able (or feel more emboldened) to make false reports to the organization.

\section{AN OVERVIEW OF THE KNAPPSCHAFTEN}

The first Knappschaften date to the Middle Ages. The early Knappschaften focused on religious observance, and on representing the miner's interests before territorial lords. Their social welfare functions developed in stages. Miners first collected voluntary contributions, following an accident, to support the injured miner or his widow and children. Later miners collected regular but still voluntary contributions to create a fund to pay for the consequences of accidents. The Knappschaft eventually adopted regular, obligatory contributions to this fund (the so-called "Büchsenpfennig"). But there was still no legal right to support from the fund; the KV remained a charitable organization rather than an insurance institution. In the final step, the law regulated both the mandatory contributions and the miner's rights to compensation from the institution's fund. This change marked the Knappschaft's transformation into institution for insurance in the modern sense. ${ }^{4}$ The Knappschaften's history reflects changes in the organization and control of mining itself. Prussia dramatically changed its mining law and administration in the 1850s. Owners obtained full control over their mines, along with the right to set wages, to hire and fire

\footnotetext{
${ }^{4}$ There is at least one example of early Knappschaften adopting a form of the insurance principle. According to Wagner-Braun, Bedeutung, p. 32, the Bergordung for Kurtrier (1546) required that miners and mine owners pay into a fund that financed medical treatment and up to four weeks of sick pay. This seems to be an exception.
} 
workers, etc. ${ }^{5}$ Each Knappschaft now decided on contributions as well as benefits for members. In 1854 the method for computing workers' contributions was changed. A KV either required each member to pay a flat percentage of his wages, or could establish a set of classes, each with a fixed annual contribution. Members had, individually, no choices about their contribution or benefit levels. The new regulations required that sick pay be paid as a fixed amount and for a total of eight weeks only. Mine owners had to contribute an amount equal to at least half of the members' contributions (this condition was restated as $\S 175$ of the 1865 Act). Changes to liability law in 1871 compensated owners for their contributions to the Knappschaften. In case of liability for the injury or death of their workers, the KV's entire contributions to the worker or his heirs were subtracted from the firm's portion of any damages. ${ }^{6}$

The 1865 Allgemeine Berggesetz (general mining law) introduced an option intended to improve the Knappschaft's ability to control costs. A Knappschaft could establish multiple funds for sickness and accident insurance while keeping a common pension fund for the membership as a whole. This new wrinkle reflected concern over Simulation. A pension fund needs a wide area to diversify risks, the argument went, but a sickness fund benefits relatively more from the ability to control costs. The new rule reflected serious moral hazard problems with Simulation in the Ruhr area especially: "This rule was the consequence of frequent malingering, which in the Ruhr area led to a great increase in costs." ${ }^{, 7}$ No Knappschaft took advantage of the new rules. Rather, they stopped giving sick pay for Sundays, and introduced a waiting period (Karenzzeit) of three days before a worker became eligible for sick pay.

The Knappschaften faced further changes when Bismarck's social insurance scheme included them in the general German insurance system. Conventional wisdom holds that Bismarck's social insurance policies marked a revolution in the role of the European state in

\footnotetext{
${ }^{5}$ The three laws were Gesetz vom 12. Mai 1851 betr. die Verhältnisse der Miteigentümer eines Bergwerks; Gesetz vom 10. April 1854 betreffend die Vereinigung der Berg-, Hütten- und Salinenarbeiter in Knappschaften; and Allgemeines Berggesetz für die preußischen Staaten vom 24. Juni 1865.

${ }^{6}$ This only applied if the firm paid at least one-third of the Knappschaft's costs. Firms were required to contribute at least one-third but could and did contribute more. See Haftpflichtgesetz betreffend der Verbindlichkeit zum Schadensersatze für die bei dem Betriebe von Eisenbahnen, Bergwerken, Fabriken, Steinbrüchen und Gräbereien herbeigeführten Tödtungen und Körperverletzungen vom 7. Juni 1871, §4.

${ }^{7}$ Wirtz, Entwicklung, p. 195. All translations from German language sources are our own; the original German text appears in the working paper version. See Guinnane and Streb, "Moral Hazard."
} 
providing social welfare. ${ }^{8}$ Historians are less sure, stressing the degree to which Bismarck simply extended the key characteristics of the Knappschaft to ever-larger numbers of German workers. ${ }^{9}$ But the Reich policy reduced the autonomy the KV had enjoyed since the 1850 s, and once the Reich scheme was introduced, the KV comprised a small part of a very large system. From the first of January 1887, KV were required to meet the standards of all other German sickness insurance funds (Betriebskrankenkassen). The new rules required many $\mathrm{KV}$ to increase both daily sick pay and the length of time workers could claim this benefit. In 1903 the Reich further increased the minimum benefits paid by institutions such as the Knappschaften, and, as of the first of January 1905, the duration for sick pay increased to 26 weeks, coupled with increased sick pay per week. ${ }^{10}$

Our discussion focuses on Prussia and Bavaria, which between them accounted for the vast majority of Knappschaften and members. Prussian legislation was also influential in the rest of Germany. Bavaria, for example, adopted the 1865 Prussian law almost without changes. The important exception to Prussian influence was Saxony, which went its own way. Unfortunately, the information we use in our econometric analysis is not available for Saxony.

\section{THE BROADER IMPLICATIONS OF THE KNAPPSCHAFTEN}

The Knappschaften will remind the reader of several different organizations that became prominent, and in some cases foundered, in the later nineteenth century. Perhaps the first institution to compare to the Knappschaft is the British Friendly Society. ${ }^{11}$ Like the Knappschaft, the Friendly Society collected contributions from members and used those funds to provide benefits to members who became ill or died. The Friendly Societies also consisted of self-governing, local organizations (called "courts"), usually amalgamated into national organizations such as the Oddfellows or the Ancient Order of Foresters. But any further parallel is misleading. Friendly Society membership was strictly voluntary, and while overseen by a Registrar of Friendly Societies, the organizations were in essence free of government control. James

\footnotetext{
${ }^{8}$ For an overview, see Hentschel, Geschichte.

${ }^{9}$ See, for example, Tampke, "Bismarcks Sozialgesetzgebung."

${ }^{10}$ A special Knappschaft law in 1906 required separate accounting for the sickness and accident insurance component on the one hand and the pension component on the other. Because the Knappschaft could still apply reserves from one fund to the other, we doubt this had any real effect on the matters we study here.

${ }^{11}$ The Friendly Society also appeared in Ireland, most of the British Commonwealth, and many continental countries.
} 
Riley stresses that to their members, the Friendly Society was as much about fellowship as financial security. ${ }^{12}$ A sick member could count on visits from other members, and his widow and orphan knew there would be a large turnout at a member's funeral. Accounts of Knappschaften sometimes stress the same idea, but, given the compulsion to join, the sense of solidarity doubtless was different.

The Friendly Societies' voluntary character led to problems that contemporaries and scholars alike hold central to their decline. First, because Friendly Societies refused to tie contributions to age, relatively few young, healthy people wanted to join. This is not the canonical adverse-selection problem caused by inability to separate potential members by their "type;" it was, rather, just that for a given annual membership fee and benefit package, only older individuals were willing to join. Riley notes that Friendly Society rules allowed them to deny membership to people who were probably bad risks, but that they rarely did so ${ }^{13}$ As a consequence, their membership grew older, and Friendly Societies found it harder and harder to fund the benefits their members expected. ${ }^{14}$

The KV did not confront the adverse-selection problem that eventually undermined the Friendly Societies. But the German funds did face problems caused by changing demographics they could not control. If a mine was worked-out and employment contracting, the relevant Knappschaft would consist of older workers. We find that the Simulation problem was worse in Knappschaften with a contracting workforce. Some of this effect reflects the health problems of older workers, but controls for member age structure suggest this effect is slight.

The Friendly Societies also faced the question of who was sick and whether some illness reflected the equivalent of Simulation. The issue was the most frequent subject of discussion at local meetings. ${ }^{15}$ Riley stresses that "friendly society members did not disagree among themselves about their ability, aided by doctors and sick visitors, to distinguish sickness from wellness. .."16 Friendly Societies adopted methods for controlling false claims that are similar to methods used

\footnotetext{
${ }^{12}$ See Riley, Sick, Not Dead, p. 37.

${ }^{13}$ Ibid., pp. 289-91.

${ }^{14}$ Wilkinson, "Friendly Society," reported in 1892 that British Friendly Societies collectively had unfunded liabilities of more than ten million pounds. Gilbert, "Decay," argues that Friendly Society opposition to universal old age insurance collapsed in the face of their own manifest inability to provide benefits, ushering in the 1908 Old Age Pensions Act. Emery's analysis of U.S. and Canadian fraternal sickness funds shows, on the other hand, that inappropriate pricing was not a serious problem for them (see Emery, "Risky Business").

${ }^{15}$ See Riley, Sick, Not Dead, p. 99.

${ }^{16}$ Ibid., p. 104.
} 
by the KV discussed below. Some appointed a special "sick steward" to check on the health status of those claiming benefits. Later on, doctors were charged with a similar responsibility. Friendly Societies also forbad those who were claiming sick pay to appear at a pub. ${ }^{17}$

E. Peter Hennock's magisterial account of the development of the welfare state in Britain and Germany provides additional useful points of comparison. ${ }^{18}$ He lays particular stress on the importance of voluntary participation in British groups, and compulsory membership in the German Knappschaften and similar, pre-social insurance organizations. $\mathrm{He}$ also provides some legislative history for the Knappschaft's role in the social insurance system. The introduction of the German system in general reflects Bismarck's political calculations. But the model owes much to Reichstag Deputy Carl Ferdinand Stumm, who owned mines and steel factories in the Saarland. Hennock and other accounts credit Stumm with the suggestion to use the Knappschaft as the model for sickness and accident insurance. ${ }^{19}$

A larger, comparative literature also bears on the Knappschaften because of the German social-insurance system's status as a model, positive or negative, for other countries. Two recent contributions to this vast literature help frame the issues. John Murray considers the actual sickness funds in operation in the United States in the late nineteenth and early twentieth centuries, as well as the European (really, German) models U.S. Progressives wanted instead. ${ }^{20}$ Many U.S. workers were insured by schemes that covered them either through their union, or through their firm, or by virtue of their membership in a voluntary sickness fund that might or might not have been, formally, a Friendly Society. Murray argues that most workers prized this coverage not because of provisions for doctors and related medical care costs, but because the funds replaced part of lost wages when a worker was ill. Doctors and hospitals could not do much for workers (or at least the workers thought). Sick pay in the U.S. funds gave rise, not surprisingly, to the same problems and arguments as in Germany; employers thought sick pay encouraged absenteeism, but others thought the benefits of a healthy and loyal workforce offset any costs associated

\footnotetext{
${ }^{17}$ Ibid., pp. 99-103. Germany's credit cooperatives evoke similar themes. These institutions faced problems of possible adverse selection at both the membership-decisions and creditdecision stages, and any credit contract faces the possibility of moral hazard. Guinnane, "Cooperatives," argues that they devised ways to draw on the dense ties of information and enforcement, implicit in their local design, to overcome these problems. The cooperatives, like Knappschaften, appreciated the possibilities of scale but were concerned that a larger organization would increase information problems.

${ }^{18}$ See Hennock, Origin.

${ }^{19}$ Ibid., p. 103.

${ }^{20}$ See Murray, Origins.
} 
with malingering. In Murray's view, the Progressive insistence on a German-style system for the United States reflected either purely political motives, or misapprehensions about what the United States already had, coupled with an idealized understanding of what the European systems had achieved. Murray acknowledges that some features of the German-style systems (such as compulsory membership) obviate some of the problems facing the U.S. funds at the time, but insists, rightly, that any insurance scheme faced information and incentive problems that the Progressives simply ignored.

A second view, most recently articulated by Jennifer Klein, dismisses the various sickness funds operating in the United States in the early twentieth century as inadequate or ineffective at best, and tools of devious employers at worst. ${ }^{21}$ Her disagreement with the kind of argument represented by Murray is based on two differences in approach. She and others who take this view probably do not appreciate how large (and, given that most were voluntary, popular) these U.S. sickness funds were. Klein may be judging these funds by a standard different from what workers at the time valued. They were not medical insurance funds; that is not what workers wanted, and to judge them by that standard confuses modern concerns with historical explanation.

\section{THE PROBLEM OF “SIMULATION”}

Some of the complaints about Simulation had a moralistic, anti-worker tone. The central issue is that the Knappschaft was insuring on an unobservable, the worker's health status. Consider, as a simplification, a myopic worker's one-day problem: whether to work or to report sick. A worker earns a wage $w$ from a day of work. Each day he draws a health status $z$, where $z$ is a uniform random variable distributed on the $[0,1]$ interval. For each day he works, the workers receives utility from income $u(w)$ and a disutility of work that depends on his health status $z, c(z)$. The utility function has the usual properties, while $c(z)$ is increasing in $z$, so a higher $z$ denotes a worse health status.

Assume first that a miner who does not work earns nothing, that is, there is no sick benefit. In this situation, a miner works if $u(w)-c(z)>$ $u(0)$ or $u(w)-u(0)>c(z)$. For a given $w$, we can define a health status $z^{*}$ implicitly such that a worker is indifferent between work and reporting sick, $u(w)-u(0)=c\left(z^{*}\right)$. On any given day, workers with health status $z$ $\geq z^{*}$ call in sick. Now suppose that a sickness fund introduces a program under which workers pay a proportion $(1-\alpha)$ of their wages into a fund

\footnotetext{
${ }^{21}$ See Klein, Rights.
} 
used to pay a benefit $b$ to miners who call in sick. Miners will now work if $u(\alpha w)-u(b)>c(z)$. We can define $z^{\mathrm{b}}$ implicitly as the health status realization that makes an insured miner indifferent between work and claiming benefit, $u(\alpha w)-u(b)=c\left(z^{\mathrm{b}}\right)$. Clearly $z^{\mathrm{b}}<z^{*}$; a fraction of workers equal to $z^{*}-z^{\mathrm{b}}$ would work if there is no benefit, but call in sick because the Knappschaft will pay $b^{22}$

Many observers referred to Simulation when increases in sick pay prompted more miners to report ill. For example, Wilhelm Bülow notes that after the introduction of new rules in the districts of Bochum and Essen, the Knappschaften there experienced a strong increase in "Simulation und Verschleppung" of diseases. ${ }^{23}$ The situation only improved when sick pay was cut by one-third. What observers wanted, apparently, was to be able to increase benefits for workers so that those with $z>z^{*}$ would have higher incomes, but without inducing any additional workers to report sick. But this was unrealistic. Health status was imperfectly observable; without additional measures, it would be only rational for workers with status from $z^{\mathrm{b}}$ to $z^{*}$ to take advantage of the benefits scheme. This is why Knappschaften introduced waiting periods and other measures, and why many observers thought it important to use social pressure to induce miners to refrain from calling in sick.

Simulation could mean, as critics claimed, that a perfectly healthy miner would get out of bed one morning and decide that he would rather go fishing, or work in his garden, than go into the mines. The greater the replacement rate, the greater the incentive to take a week off at Knappschaft expense. Workers also took off time to heal from illness or injury. Mining was hard, dangerous work. Miners would come home from a day's work with bruises and muscle strains that required several days' recuperation. The miner could, in fact, work the next day, but had good reason not to want to. The effect of the Knappschaft benefit in this less moralistic exposition is to reduce the cost to the miner of time to heal. Allowing miners to recuperate fully might well have been efficient rather than evidence of incentive problems. A third behavior is also relevant. Simulation and Verschleppung are both translated in English as "malingering," but the former implies that the condition is invented,

\footnotetext{
${ }^{22}$ Modern studies of the effect of unemployment insurance and related programs identify the "replacement rate" or benefits as a fraction of working pay, as a key control variable. In our terms, this is $b / \alpha w$. We do not observe this measure in systematic fashion. Lauf, "Knappschaftsvereine," p. 281, reports that the Knappschaft in the Rhein and Ruhr areas paid about 60 percent of the daily wage for sick workers. Other accounts sound similar. This sick pay was in addition to the costs of medical attention and supplies.

${ }^{23}$ See Bülow, Knappschaftswesen, p. 64.
} 
and the later implies that the condition was real but the sufferer has exaggerated its duration.

The literature makes several suggestions as to why Simulation increased in the later nineteenth century. Some authors argue that the 1854 Prussian law, which converted miners from a privileged Stand to ordinary proletarians, was the root of the problem. Ulrich Lauf refers to a wave of protest at the demotion of the Knappschaft from the institutional symbol of that special status to the more prosaic role of insurance provider. ${ }^{24}$ We cannot test that claim, as the change proceeds the period for which we have useful data. Two other claims are testable. The first is that KV size promoted moral hazard. In a large Knappschaft, a miner felt less that abusing the system was hurting someone to whom he had real social ties. Observers often noted that miners were in a better position than others to know who was really unable to work, and that the risk of ill will from fellow miners was an effective deterrent. This amounts to imposing an additional disutility, in the form of worker opprobrium, on those who call in sick when they in fact have a low draw of $z$. In this case, the Knappschaft could increase $b$ without increasing the numbers calling in sick; in effect, this extension relies on the assumption that fellow miners could overcome the information problem.

There were frequent claims about the relationship between $\mathrm{KV}$ costs and either the Knappschaft's size (membership) or the area over which it was spread. In discussing Saxon Knappschaften, Ulrich Elsholz explicitly argues that in a small organization workers will apply informal sanctions on malingering workers, and that if they are spread out in several different mines this is not possible. ". . . For sickness funds, small and local organizations (Gebilde) are needed, because the fund benefits if workers have an interest in thwarting Simulation." 25 Peter Simons and August Wirtz make similar arguments, and Lauf notes that the need to reduce the size of the insured group was a theme from the $1880 \mathrm{ss}^{26}$ Some KV were huge, and some enterprises had grown so large that it would be hard to feel any sense of solidarity just within the single enterprise. In our data, the median works has 121 Knappschaft members employed. But one KV had over ten thousand workers per enterprise.

The Reich's interventions, requiring greater sick pay and longer periods of coverage, also contributed to the problem. Higher sick pay

\footnotetext{
${ }^{24}$ See Lauf, "Knappschaftsvereine," p. 266.

${ }^{25}$ Elsholz, Entwicklung, p. 36.

${ }^{26}$ See Simons, Knappschaftswesen, p. 8; Wirtz, Entwicklung, p. 105; and Lauf, "Knappschaftsvereine," p. 271.
} 
would lead to more Simulation by reducing the cost of time off. The longer benefits period would also encourage Simulation. The waiting period (Karenzzeit) is like an investment for the worker; by extending the benefit period, the government reduced the cost of that investment relative to the payback.

A final argument implies that the sick pay was used as a substitute for unemployment insurance. Several commentators noted that Simulation became a more serious problem during downturns in the covered industries. Sick pay was set as a fixed daily sum, but the worker's income depended on demand for their product. ${ }^{27}$ This implies that the replacement rate varied over the business cycle, increasing as economic conditions worsened. ${ }^{28}$ Downturns led to considerable Simulation, according to Elmar Menzel who quotes an 1894 eyewitness at a later date. ". . Simulation increases especially in bad times. When wages fall, that is, when workers worked only part time, then the experience is that sicknesses increase and with them the costs for the sickness fund. ${ }^{29}$ Menzel's eyewitness also claimed that firms encouraged Simulation in downturns, tacitly turning the Knappschaft into a form of unemployment insurance.

\section{Combating the Problem}

Knappschaften were aware of the moral hazard problem and adopted measures to reduce Simulation. ${ }^{30}$ Some tactics took for granted that additional information on the health status of the miners would be too difficult to acquire, and instead tried to create the desired separating equilibrium by reducing the attractiveness of being ill while holding sick pay fixed. Some KV required that those receiving medical treatment and sick pay remain in hospital (Lazarettzwang). ${ }^{31}$ Miners detested this policy, although we cannot say whether it was because it made recuperation more unpleasant or malingering harder. According to

\footnotetext{
${ }^{27}$ Ashton, "Relation," notes this same effect for the British Amalgamated Society of Engineers. Whiteside, "Cost," discusses the same issue for Britain in the 1920s and 1930s. German miners were paid a team piece rate. The rate was renegotiated at regular intervals, implying that the rate would track current output prices. See Banken, Industrialisierung, p. $100 \mathrm{ff}$.

${ }^{28}$ In the 1870 s, for example, a serious downturn reduced the demand for coal and thus the miners's daily income from work. Gerhard Bry reports an index of shift earnings for Dortmund miners. This index $(1913=100)$ falls from 77 in 1873 to 39 in 1879. Overall, the coefficient of variation for the index in the period 1871-1914 is 27 percent, indicating that miners faced large fluctuations in the demand for their labor. See Bry, Wages, table A-8.

${ }^{29}$ Menzel, Bergbau-Medizin, p. 102.

${ }^{30}$ For more detail on the measures discussed here, see Bluma, Schulz, and Streb, "PrinzipalAgenten-Probleme."

${ }^{31}$ Silesian Knappschaften pioneered the development of specialized hospitals for the treatment of miners. See Lauf, Krankenhäuser, p. 81.
} 
Lauf, the rules of the Upper Silesia association required all illness to be treated in hospital. ${ }^{32}$ The results of the policy were impressive: for the period 1901-1908 this Knappschaft experienced 6.4 sick days per member, compared to 10.8 for other Prussian Knappschaften and 7.6 for Germany as a whole. Unfortunately, we cannot test the implications of the hospitalization policy directly.

Knappschaften were also aware of the role the waiting period played in discouraging Simulation. ${ }^{33}$ Wirtz notes that when the Ruhr Knappschaften introduced a policy in 1867 of making claimants wait three days (not including a Sunday) to receive payment, they could increase sick pay per day by 50 percent and still reduce total costs. ${ }^{34}$ Other policies tried, in effect, to develop better information on who was truly ill. Smaller Knappschaften hired local doctors on a part-time basis, while larger associations had full-time staff. Most doctors were assigned a specific set of workers as their responsibility, and were paid a fixed sum per worker per year, healthy or ill. This might have reduced simulation if the doctor would reduce his time commitments by refusing to coddle miners who were not ill. On the other hand, the doctor might have found it easier to accede to miners' demands that were not medically justified. This "parish" (Sprengel) system for doctors preceded the 1865 reforms; Bülow reports its existence in the Märkischer KV from 1840. ${ }^{35}$

In other cases, the worker representatives to the $\mathrm{KV}$ management, or their designees, oversaw certification of sick cases. This put the representatives in the position of policing Simulation and the practice was resented by workers. Some Knappschaften hired additional employees to help deal with the problem. The Bochum Allgemeine Knappschaftsverein introduced in 1893 a system whereby trustees (Vertrauensmänner) could pay home visits to any worker who claimed to be ill. They visited nearly 40 percent of sick members, a figure high enough presumably to worry those who made false claims. ${ }^{36}$ Bülow notes that the Märkischer Knappschaftsverein introduced a special

\footnotetext{
${ }^{32}$ See Lauf, "Knappschaftsvereine," p. 284; and Köhne, Knappschaftsvereine, p. 38. Heinrich Imbusch, Knappschaftswesen, p. 42, notes that this Knappschaft owned nine of its own hospitals, and that in 1881, 69 percent of its sick members were treated there (the implication being that the rest were treated in hospitals not owned by the Knappschaft). This hospital rule echoes the arguments made for the "workhouse test" under England's New Poor Law. The workhouse was expensive, but by forcing paupers to receive relief there, the workhouse both screened out applicants who were not truly in need, and it increased incentives to take actions that would keep the person from needing the Poor Law. See Besley, Coate, and Guinnane, "Incentives."

${ }^{33}$ Friendly Societies used a similar waiting period (see Riley, Sick, Not Dead, p. 283), as did many of the sickness funds studied by Murray.

${ }^{34}$ See Wirtz, Entwicklung, p. 106.

${ }^{35}$ See Bülow, Knappschaftswesen, p. 33.

${ }^{36}$ See Lauf, "Knappschaftsvereine," p. 288.
} 
"sickness controller" for Bochum in 1860, but that, in the face of considerable protest the KV management backed down. ${ }^{37}$ If this type of system could be made to work, it would reduce Simulation. But Riley argues that the equivalent in Friendly Societies were viewed as spies. ${ }^{38}$ To the extent the Knappschaft's methods undermined the solidarity that made miners thinking of the organization as their own, such methods could backfire.

\section{EMPIRICAL STRATEGY}

The rest of this article reports indirect tests for the existence of moral hazard. We rely heavily on the rich annual reports the Knappschaften made to either the Prussian or Bavarian governments. Unfortunately, the data seem to be available only for Prussia and Bavaria. This limitation is not as serious as it might seem. Prussia accounted for about half of Knappschaften, and Tobias Jopp estimates that 90 percent of German miners were in Prussia alone about $1900 .{ }^{39}$ The data were published separately for each Knappschaft, grouped together in large administrative districts (Oberbergamtsbezirk in Prussia, Berginspektionsbezirk in Bavaria) that correspond to the government apparatus for oversight of mines and Knappschaften. The districts are named for the cities where their offices were located: Bonn, Breslau, Clausthal, Dortmund, and Halle in Prussia; and Bayreuth, München, and Zweibrücken in Bavaria. Figure 2 is a map of Germany, using its pre-1918 borders, that locates each region. ${ }^{40}$ These regions comprise the primary mining areas located in Prussia, as well as most of those located in Bavaria, and include the vast majority of all Knappschaften in Germany. Our data allow us to overcome problems that have limited earlier efforts to examine moral hazard and related problems in historical sickness funds. Earlier works by Murray and others (cited above) do not have panels based on fund-level information. Cross-sectional data do not support disentangling moral hazard from unobserved heterogeneity in the data. Panels in which the units of observation are provinces or countries, another approach, suffer from a different version of the same problem. We know the age composition of our KV members, for example, and can control for that in our models. More generally, our panel allows us to control for unobserved

\footnotetext{
${ }^{37}$ See Bülow, Knappschaftswesen, p. 34.

${ }^{38}$ See Riley, Sick, Not Dead, p. 101.

${ }^{39}$ See Jopp, "Geschäft."

${ }^{40}$ Appendix A in the working paper version gives precise sources for the variables we use.
} 


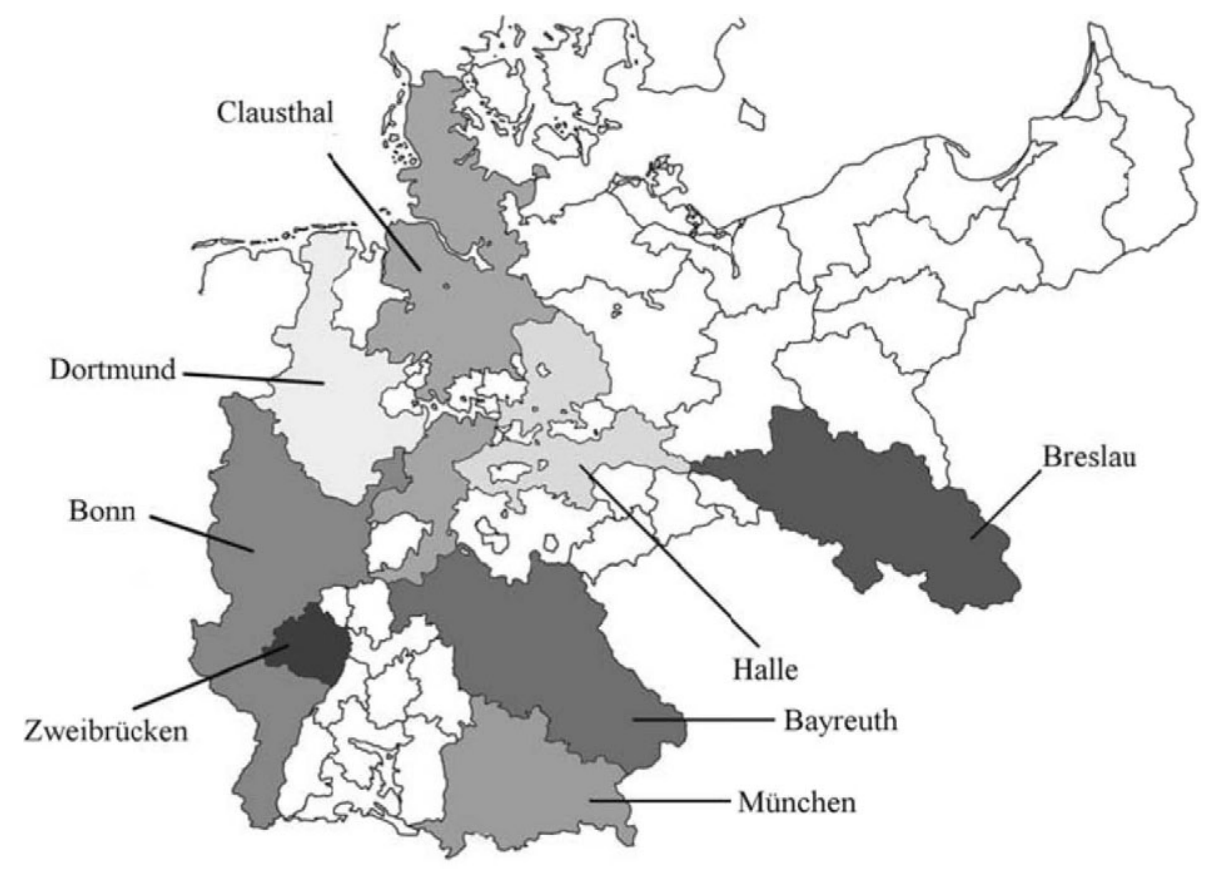

FIGURE 2

LOCATOR MAP OF THE MINING ADMINISTRATION REGIONS

(Oberbergamtsbezirke)

Note: White areas are those lacking mines or outside the mining regions administered by Prussia and Bavaria. We refer to the districts by the name of the city from which the district was administered.

heterogeneity among Knappschaften. Thus our parameters tell us the response of workers in specific Knappschaften to changes in their funds' policies.

One reason Knappschaften varied greatly in size was that some small ones merged. Prussia saw a long series of fusions in which a larger KV absorbed a smaller. Sometimes the same KV was involved twice; the Märkischer KV, for example, absorbed the Königsberger $\mathrm{KV}$ in 1877, and in turn was one of the three Knappschaften that merged to form the huge Allgemeiner Knappschaftsverein Bochum in 1890. Fusion was less common in Bavaria, although in 1902, ten KVs joined to form the new Knappschaftsverein Bayreuth. ${ }^{41}$ The possibility of fusion raises a problem that we do not address in this article: at some level, Knappschaft size was endogenous. Suppose the member's desire to keep their small organization separate reflected, in part, their fear that the members of a larger organization would have different preferences,

\footnotetext{
${ }^{41}$ Jopp, "Welfare State," discusses the fusions in more detail.
} 
and that the preferences of the original members not be reflected in the policies of the new body. This logic implies that size is correlated with member preferences, which makes size endogenous in the models we estimate. We have a partial defense for our current approach. In some cases, the government "suggested" that small Knappschaften merge. We do not know the full range of pressure the government might have brought in those cases, so cannot speculate on how voluntary mergers really were. ${ }^{42}$

\section{Econometric Issues}

We report only fixed-effects (FE) estimates of our models. The substance of our data suggests the fixed-effects model, since we have the universe of Knappschaften in Prussia and Bavaria, not a sample. ${ }^{43}$ The more important issue facing this research concerns the potential endogeneity of an important regressor. We do not have precise information on the benefit schedules for workers in the various Knappschaften. Instead, we use the average benefit, computed by dividing total sick benefit payments by the total number of days the benefit was paid to members who received such payments (Sick pay per day). This variable reflects the balance of two forces. First, a higher replacement rate would encourage workers to report ill. Second, a higher replacement rate encourages the $\mathrm{KV}$ to take stronger measures to control Simulation. Sick pay per day is arguably endogenous, because a Knappschaft whose workers experienced higher rates of sickness would

\footnotetext{
${ }^{42}$ We have been unable, despite considerable effort, to locate archival material that would allow us to examine the effect of Knappschaft policies on the behavior of individual workers. We are forced to work with aggregates by Knappschaft-year. Thus we are unable to determine whether a particular policy affects all members a little or a minority of members a great deal. There are two other limitations to the data. The first is some missing years, which we do not think we can overcome because the Knappschaft never sent in the requisite report. For single years, this problem is not terribly important; it just means that our panel is not quite fully balanced. (The panel is also unbalanced because of the way we treat fusions.)

${ }^{43}$ In any case, Hausman-type tests reject the random-effects model in favor of the FE model. Panel models of this sort raise a number of questions about estimation strategy that we have done our best to investigate. One is whether the "between effects" (BE) estimator, which estimates the model parameters using variation across $\mathrm{KV}$ is preferable to the fixed-effects approach we use here. We believe the FE to be the better approach, because it allows us to clean out unobserved heterogeneity at the KV level. We did estimate all FE models reported here with the BE estimator. The results differ (if the BE and FE estimates were identical, then the random effects estimator would be consistent) but the BE estimates usually have the same signs as what we report below. A second concern is that if our data exhibit an autoregressive (AR) process, then our estimates would be consistent but inefficient, and that our standard errors would be incorrect. Reestimating the models with estimators robust to AR processes suggests this is not a serious issue. Finally, one might worry about dynamic processes; for example, a KV's reaction to past worker behavior might affect future worker behavior. We experimented with dynamic panel models and the results are broadly similar to those we report.
} 
want to reduce benefits. The effect could also appear over time; as sick days increased, the KV could react by reducing sick pay, as several of our examples imply. As an instrument for Sick pay per day, we require a variable that is correlated with Sick pay per day but uncorrelated with the error term in our second-stage equation. The IV results reported here all use the firm's contribution per KV member (Firm costs per member) as an instrument for the generosity of sick pay. This instrument meets the exclusion restriction, as there is no reason to think miners cared about the firm's per-member costs in deciding whether to report sick. The "first-stage" regressions we report below also show that the instrument is strongly correlated with the endogenous variable, as it must be. ${ }^{44}$

In much of our analysis, we divide the Knappschaften into two groups and estimate separate but identical specifications. ${ }^{45}$ This approach reflects the robust finding that larger, more rapidly growing $\mathrm{KV}$ behaved differently from the smaller, shrinking associations. We cannot say precisely why this relationship holds so strongly, but suspect that it reflects differences in perceptions of the future. A worker presumably thinks differently about abusing an institution he doubts will exist in ten years. One could think of the distinction as size or growth rate of membership. The growth rate distinction is more robust. The precise dividing line does not affect the results; here we split the data at the median growth rate of 1.8 percent per year. Splitting the data at a growth rate of zero produces nearly identical results, as does dividing the Knappschaften according to membership size, with the dividing line at 200 members.

\section{Definitions and Proxies}

We use several proxies and definitions that require discussion. Table 1 defines and gives descriptive statistics for each of the variables in our regressions. We employ two different measures of the size of the unit in which workers operated. One is the total size of the KV (KV members),

\footnotetext{
${ }^{44}$ Recent discussions of the problem of weak instruments suggest as a rule of thumb that the $F$-statistic associated with exclusion of the instrument in the first stage be at least 10 . The relevant $t$-statistics here, which in this case are the square root of $F$, usually exceed 3.16. For a cogent discussion of the weak-instrument issue, see Bound et al., "Problems."

${ }^{45}$ In some IV specifications for the stagnant $\mathrm{KV}$, the point estimates are worryingly large but imprecisely estimated. This reflects a scaling problem, not a specification error. We retain the current scaling to make all regressions easily comparable.
} 
TABLE 1

MEANS, STANDARD DEVIATIONS, AND DEFINITIONS OF MAIN VARIABLES

\begin{tabular}{|c|c|c|c|}
\hline Variable Name & Mean & S.D. & Definition \\
\hline Sick days & 7.42 & 4.54 & Number of sick days per KV member \\
\hline Sick cases & .63 & .33 & Number of cases of illness per KV member \\
\hline Sickness length & 13.55 & 6.50 & Average number of days for each sick case \\
\hline Sick pay per day & 0.95 & 0.63 & Mean sick pay per sick day (marks) \\
\hline Firm's portion of costs & 0.43 & 0.11 & Portion of all KV costs paid by firms \\
\hline KV Members & 4.06 & 17.07 & Total membership of KV ('000s) \\
\hline Workers per unit & 0.32 & 0.57 & Membership per works ('000s) \\
\hline Coal production & 14.09 & 11.91 & $\begin{array}{l}\text { Coal production (defined at regional level) } \\
\text { (millions of tons) }\end{array}$ \\
\hline Firm part per member & 22.20 & 28.57 & $\begin{array}{l}\text { Total firm contributions to } \mathrm{KV} \text {, per } \mathrm{KV} \\
\text { member (marks) }\end{array}$ \\
\hline Rheum & 0.10 & 0.11 & Rheumatism cases per KV member \\
\hline Contus & 0.06 & 0.05 & Contusion cases per KV member \\
\hline
\end{tabular}

Note: Means and standard deviations are pooled across all years and Knappschaften.

while the other is the number of members per works (Workers per unit). Another important variable is the fraction of total $\mathrm{KV}$ expenses born by the owners (Firm's portion of costs).

Because we can use panel models, unobserved heterogeneity across Knappschaften is less of a concern than it might be in other contexts. In particular, one might worry that the type of product produced might affect the incidence of illness or accident in a given Knappschaft. Of course, we are interested in how reported sick days responds to sick pay, and any shift in the level of sickness due to product differences would be absorbed into the fixed effects. Nonetheless, we do have, for a subsample of our Knappschaften, data on the type of mines their members worked in. Introducing controls for hard coal, soft coal, etc., did not materially affect our results, and forced us to exclude a large part of the sample. Similarly, the age distribution of KV members, which we again have for Prussia in some years, makes no difference in our regressions. Thus those (unnecessary) controls are not in the models reported here.

Some arguments made by contemporaries imply that Simulation would respond to the demand for miner's labor. To test this claim precisely 
would require $\mathrm{KV}$-level production data, which is not available. As proxies, we have assembled annual data on output of key products such as coal. Unfortunately, this information is not available at any level less aggregated than the Oberbergamtsbezirk. We experimented with the production of hard coal and brown coal as reasonable proxies. In some specifications, we interact the proxies with a dummy for whether the KV in question had any mines of that type; in others, we found that hard coal production (coal production) alone was a good proxy.

\section{Empirical Implications of Simulation and Verschleppung}

We employ two distinct strategies for identifying Simulation. Our first strategy relies on the fact that some diseases are more easily verified than others, and thus speaks directly to the underlying issue, which is the imperfect observability of health status. Presumably a miner who claims to have a broken leg cannot fool his doctor about this fact. But other diseases were another matter. Contemporaries focused on the fact that rheumatism was a sort of unverifiable catchall term. Today, we associate rheumatism with conditions that are real and in most cases subject to clear-cut medical tests. We do not mean to suggest that many miners were not suffering from the same, given the dampness and changing temperatures they experienced in their work. Rheumatism was and remains a particular problem in mining. According to Menzel, in the years before 1881, the military and the postal service saw five to seven cases per 100 workers annually of rheumatism. ${ }^{46}$ For miners, this figure was nine to twenty new cases per 100 workers. German miners still face this condition: in 1986, 23 percent of all sick cases implying inability to work were related to rheumatism. ${ }^{47}$

But it was easy in the nineteenth century to claim rheumatism as a cover for Simulation. Menzel cites a Knappschaft doctor who claimed that, "The word 'rheumatism' excites in the populace a general sympathy, pleasing both patient and doctor. . . nobody knows what rheumatism is. The word serves often as a cover for ignorance, as the last refuge in cases where the doctor seems to have been convinced that his patient, although objectively in good health, is suffering." ${ }^{48}$ Dr. Isak Schlockow drew a direct connection between rheumatism reports and Simulation, noting that this condition was easier to fake than others. ${ }^{49} \mathrm{He}$ buttresses this view with the observation that in the Upper Silesian Knappschaft, where

\footnotetext{
${ }^{46}$ See Menzel, Bergbau-Medizin, p. 191.

${ }^{47}$ Ibid., p. 200.

${ }^{48}$ Ibid., p. 186.

${ }^{49}$ See Schlockow, Gesundheitspflege, p. 160.
} 
sickness had to be treated in hospital, rheumatism affected 4.8 of every hundred members per year. The similar figure for Clausthal was 26.7! There were no significant improvements in detection or treatment of rheumatism in the period we discuss, so we do not have to worry that our estimates reflect changing technologies.

Our second strategy corresponds to the approach taken in earlier work on this topic, and is more severe. If illness were perfectly observable and caused only by random shocks, as one expects, then there would be no relationship between sick days and the size or composition of payments to workers. Similarly, sick days would not be associated with the size of the KV or individual production units. The second set of models all rely on the presumption that such correlations reflect some type of moral hazard. There are two reasons to be cautious about this approach. One is that our results are consistent with a worker having minor injuries and being more likely to stay home to recuperate when, for example, sick pay increases. As noted, it is not clear that we want to assume such conduct reflects information problems. A second concern is that these correlations could arise out of omitted variables bias or some other specification problem. Suppose, for example, that work in larger production units is objectively more dangerous than in other contexts. Then a finding that reported sick days increased with the size of the production unit would not necessarily be evidence of moral hazard alone. To the extent this unobserved heterogeneity is linear and additive, our fixed-effects models will sweep that away. We recognize that this second group of tests is demanding. ${ }^{50}$

\section{EVIDENCE FROM CAUSES OF ILLNESS}

The apparent incidence of rheumatism varied dramatically across $\mathrm{KV}$. In the median year, most Knappschaften saw fewer than ten such claims per hundred members. The exceptions tended to be extreme. The Neusalzwerker KV had 55 claims per 100 members in some years. More instructive is the apparent persistence of this rheumatism crisis. For three-quarters of the years in our data, the Neusalzwerker KV had at

\footnotetext{
${ }^{50}$ Several earlier studies test for moral hazard in funds of this type. Our sick pay measure is identical to that used by Murray, "Worker Absenteeism." Our approach in section six is also very similar to his. Our data differs from earlier studies in two respects. Some data sets have individual-level data on actual or potential fund members (for example, some sources used in Murray, Origins, as well as Gottlieb, "Asymmetric Information." But these sources are always a single cross-section, making it difficult to distinguish moral hazard from unobserved heterogeneity. (Murray, "Worker Abesenteeism," also uses a panel in which the observations are country-years). Our data set is unusual in that it is fund-level.
} 
least 47 reports of rheumatism per 100 members. This empirical pattern suggests a simple test for the presence of moral hazard: do lost work days due to rheumatism vary differently from reports of other causes of illness? More precisely, do the determinants of rheumatism cases suggest that it was used, as suggested, as a cover for Simulation? As a control, we compare the data on rheumatism to the data on bruises and contusions (contus) ${ }^{51}$ Contusions were a fact of life for miners, and legitimately led to lost days of work. But unlike rheumatism, contusions are normally entirely observable to a medical practitioner. Moreover, most accidents leading to bruises and contusions would be well-known to other miners, whereas a worker with true rheumatism has no way of credibly signaling that fact to his fellows.

In the working paper version of this article, we report the unweighted means and standard deviations of the incidence of rheumatism and contusions in Prussia (Bavarian Knappschaften did not report this information). ${ }^{52}$ Two patterns stand out. Over the period for which we have this information (1867-1884), rheumatism became relatively less common, but it varied much more dramatically over time than did reports of contusions. And the dispersion of apparent rheumatism across Knappschaften was significantly greater than for contusions. This information strongly suggests that rheumatism was being used as a cover for Simulation; the underlying "true" causes of the condition would not vary as much over time or across Knappschaften. Table 2 reports FE estimates of the determinants of the difference between reported rheumatism and contusions in a given $\mathrm{KV}$, separately for the stagnant and dynamic KVs. This "difference" approach allows us to control in a clean way for cross-KV differences in factors that affect either type of illness. We estimated (but do not report) models in which the dependent variables are rheumatism cases on the one hand, and contusions on the other, and those suggest that most of the correlation between the difference and the right-hand side variables in our models reflects correlations with rheumatism. The models discussed in this section tend to be fragile. We experimented with several different approaches. The underlying problem is that data on illness stops in 1884 , and some KV were not always consistent in even reporting the data. Table 3 gives elasticities pertaining to the models reported in Table 2. The instrument for Sick pay per day here is as noted above;

\footnotetext{
${ }^{51}$ Some KV reported various types of rheumatism and contusions. We aggregate them into two general categories.

${ }^{52}$ Guinnane and Streb, "Moral Hazard," Figures 4 and 5.
} 
TABLE 2

DETERMINANTS OF THE DIFFERENCE BETWEEN RHEUMATISM AND CONTUSIONS, $1867-1884$

\begin{tabular}{lccc}
\hline \hline & $(1)$ & $(2)$ & $(3)$ \\
\cline { 2 - 4 } & FE/ & FE/ & FE/ \\
& 0.182 & 0.327 & 0.111 \\
Sick pay per day & $(2.069)$ & $(2.341)$ & $(0.817)$ \\
Firm's portion of costs & 0.043 & 0.210 & 0.040 \\
KV members & $(0.717)$ & $(2.014)$ & $(0.417)$ \\
Workers/Unit & -0.005 & -0.016 & -0.002 \\
& $(-0.940)$ & $(-1.394)$ & $(-0.316)$ \\
Soft coal & -0.011 & 0.019 & -0.029 \\
& $(-0.596)$ & $(0.577)$ & $(-1.054)$ \\
Hard coal & 0.008 & -0.061 & 0.046 \\
& $(0.250)$ & $(-0.993)$ & $(1.140)$ \\
Constant & 0.001 & 0.001 & 0.002 \\
& $(0.424)$ & $(0.167)$ & $(0.597)$ \\
Observations & -0.050 & -0.177 & -0.018 \\
Number of Knappschaften & $(-1.342)$ & $(-1.962)$ & $(-0.432)$ \\
& & & \\
Notes: Nomic KV & & 231 & 297 \\
& 528 & 19 & 37 \\
\hline
\end{tabular}

Notes: Numbers in parenthesis are $t$-ratios. The dependent variable is the number of cases of rheumatism minus the number of cases of contusions. We instrument sick pay per day with firm part per member in all three equations. Stagnant KV are defined as those whose average annual membership growth over the period 1867-1914 was less than 1.8 percent per year, which is the median growth rate. The rest are defined as dynamic KVs.

the $t$-statistic for the instrument in the first stage for all models reported in Table 2 exceeds 3.5, except that reported in column 2. Reestimating that particular model without the instrument produces, not surprisingly, results similar to those reported. The models include year effects, but they are not statistically significant. The results show that rheumatism responded strongly to increases in Sick pay per day and, for stagnant $\mathrm{KV}$, to increases in the portion of total costs covered by the firms. The dynamic KV did not experience this problem; the estimate is positive but small and not statistically significant.

\section{EVIDENCE FROM SICK DAYS AND CASES}

The rheumatism proxy yields sharp results, but only for part of our period. We turn next to measures of the overall behavior of miners in a Knappschaft: how many claimed to be sick and for how long, and how those measures varied with incentives. There are several ways to 
TABLE 3

ELASTICITIES COMPUTED FROM CAUSE-OF-ILLNESS MODEL: DIFFERENCE BETWEEN RHEUMATISM AND CONTUSIONS

\begin{tabular}{|c|c|c|}
\hline & Stagnant KVs & Dynamic KVs \\
\hline & Fixed-Effects Model & Fixed-Effects Model \\
\hline $\begin{array}{l}\text { Elasticities evaluated at } \\
\text { mean: }\end{array}$ & & \\
\hline Sick pay per day & 7.10 & 2.85 \\
\hline Firm's portion of costs & 2.83 & .63 \\
\hline KV members & -.97 & -.24 \\
\hline Workers/Unit & .17 & -.38 \\
\hline Soft coal production & -.09 & .06 \\
\hline Hard coal production & .03 & .20 \\
\hline
\end{tabular}

measure the extent to which miners drew on sick pay. One measure is available for all $\mathrm{KV}$ for the entire range of our data set, and that is the total number of sick days for the Knappschaft in a year, divided by its membership in that year. Only the Prussian KV reported the data needed for two additional measures, unfortunately. One is the total number of cases of illness in the year, and the second is the mean number of days lost per case of illness.

We begin with days of illness per Knappschaft member, for which we have complete information. Tables $4 \mathrm{~A}$ and $4 \mathrm{~B}$ report three fixedeffects models each for all KV (columns 1-3), for those growing more rapidly than the median (columns 4-6), and for those growing more slowly than the median (columns 7-9). For each group, we report a FE regression, an analogous FE IV regression, and the "first stage" from that IV regression. The first stage has independent, substantive interest, because it amounts to a model of how sick pay is determined. Our regressors include Sick pay per day and Firm's portion of costs, which reflect the extent to the miner can take a day off at someone else's expense, as well as two measures of size, $K V$ members and Workers per unit, which measure the putative size effect in moral hazard. The regressions include the coal variable used to proxy for the demand for member labor. We introduce dummies for 1887 and later and 1905 and later, to capture any influence of the Reich policy changes. ${ }^{53}$ (Table 7 collects the main elasticities from models we discuss in this section).

${ }^{53}$ These and later regressions include unreported controls for the age structure of the Knappschaft's 
TABLE 4A

DETERMINANTS OF SICK DAYS PER KNAPPSCHAFT MEMBER

(1)

(2)

(3)

All Knappschaften

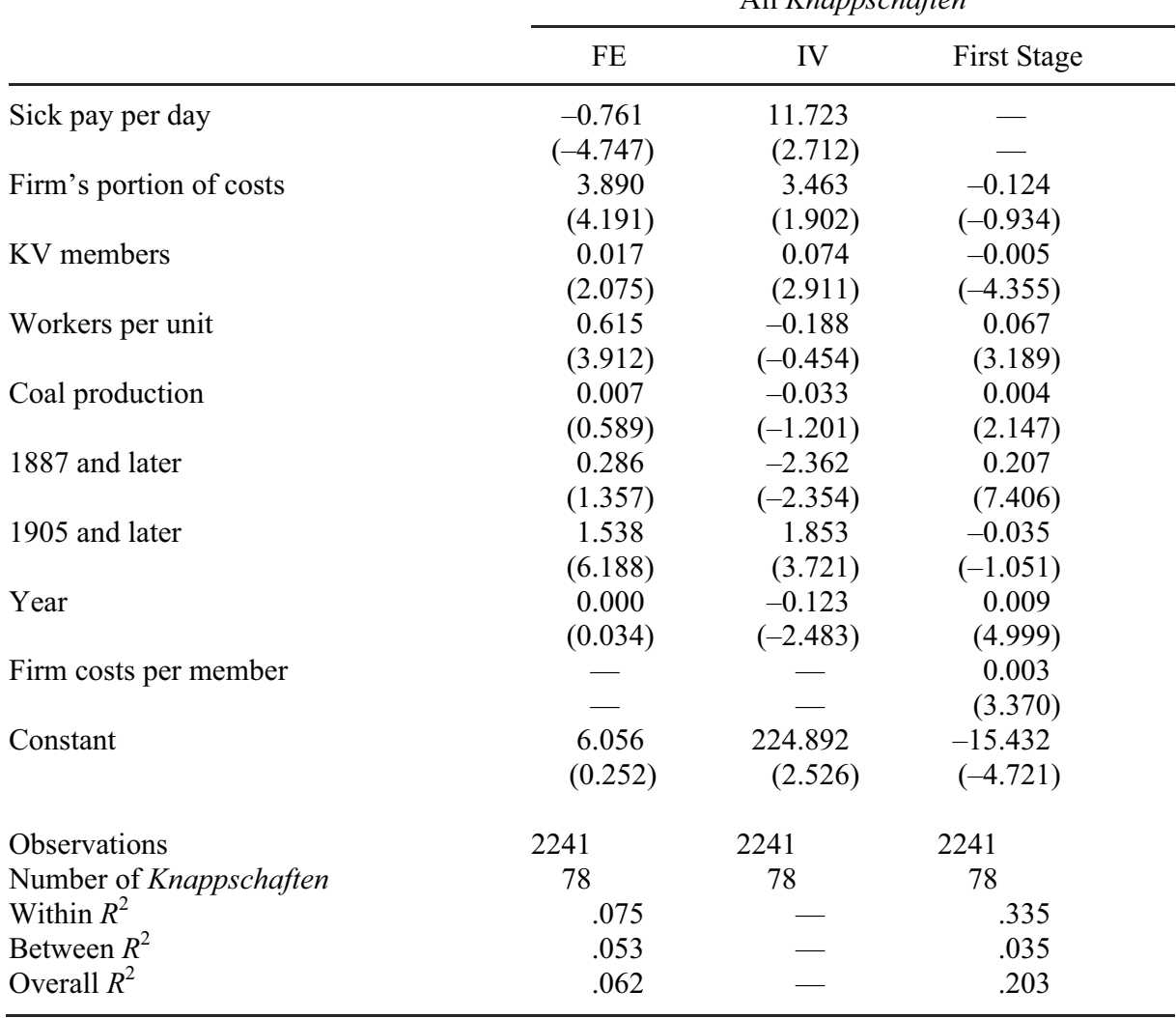

Note: All models include Knappschaft-level fixed effects and controls for age structure.

The IV models demonstrate the importance of treating Sick pay per day as endogenous. In the basic FE model, sick pay has a negative effect, which is precisely what the reverse causation would imply, if the $\mathrm{KV}$ were reducing benefits in response to increases in sick pay. In the IV specifications, it is always either positive or effectively zero, which is what we expect: the greater the sick pay, the greater the incentive to report sick. Focusing on the IV results, we see that the model does not explain behavior in the slow-growing KV well. Most impacts are

membership. Collectively, these controls are always only borderline significant. Surprisingly, older workers seemed less likely to claim sick pay. This correlation may reflect the practice of allowing older miners to shift to less dangerous work often on the surface. Seriously disabled workers were also shifted out of the Knappschaft's sickness scheme and into a distinct fund that handled disability, which may also account for the weak age effects. 
TABLE 4B

DETERMINANTS OF SICK DAYS PER KNAPPSCHAFT MEMBER

\begin{tabular}{|c|c|c|c|c|c|c|}
\hline & (4) & (5) & (6) & (7) & (8) & (9) \\
\hline & \multicolumn{3}{|c|}{ Dynamic KV } & \multicolumn{3}{|c|}{ Stagnant KV } \\
\hline & $\mathrm{FE}$ & IV & First Stage & FE & IV & First Stage \\
\hline Sick pay per day & $\begin{array}{l}-1.453 \\
(-4.882)\end{array}$ & $\begin{array}{l}-2.256 \\
(-1.240)\end{array}$ & - & $\begin{array}{c}-0.557 \\
(-2.802)\end{array}$ & $\begin{array}{r}220.881 \\
(0.267)\end{array}$ & - \\
\hline $\begin{array}{l}\text { Firm's portion of } \\
\text { costs }\end{array}$ & $\begin{array}{c}3.549 \\
(3.407)\end{array}$ & $\begin{array}{c}3.711 \\
(3.356)\end{array}$ & $\begin{array}{c}0.015 \\
(0.143)\end{array}$ & $\begin{array}{c}2.804 \\
(1.653)\end{array}$ & $\begin{array}{l}71.451 \\
(0.271)\end{array}$ & $\begin{array}{l}-0.352 \\
(-1.083)\end{array}$ \\
\hline $\mathrm{KV}$ members & $\begin{array}{c}0.019 \\
(2.540)\end{array}$ & $\begin{array}{c}0.016 \\
(1.447)\end{array}$ & $\begin{array}{l}-0.005 \\
(-6.726)\end{array}$ & $\begin{array}{c}-1.275 \\
(-6.295)\end{array}$ & $\begin{array}{l}-4.918 \\
(-0.316)\end{array}$ & $\begin{array}{c}0.019 \\
(0.540)\end{array}$ \\
\hline Workers per unit & $\begin{array}{c}0.852 \\
(5.757)\end{array}$ & $\begin{array}{c}0.896 \\
(5.031)\end{array}$ & $\begin{array}{c}0.056 \\
(4.056)\end{array}$ & $\begin{array}{l}-0.680 \\
(-0.872)\end{array}$ & $\begin{array}{l}-2.769 \\
(-0.092)\end{array}$ & $\begin{array}{c}0.012 \\
(0.091)\end{array}$ \\
\hline Coal production & $\begin{array}{c}0.023 \\
(1.806)\end{array}$ & $\begin{array}{c}0.028 \\
(1.632)\end{array}$ & $\begin{array}{c}0.007 \\
(5.769)\end{array}$ & $\begin{array}{l}-0.019 \\
(-0.687)\end{array}$ & $\begin{array}{c}0.895 \\
(0.251)\end{array}$ & $\begin{array}{l}-0.004 \\
(-0.863)\end{array}$ \\
\hline 1887 and later & $\begin{array}{l}1.060 \\
(4.126)\end{array}$ & $\begin{array}{l}1.235 \\
(2.637)\end{array}$ & $\begin{array}{c}0.210 \\
(8.982)\end{array}$ & $\begin{array}{l}-0.451 \\
(-1.303)\end{array}$ & $\begin{array}{l}-45.309 \\
(-0.270)\end{array}$ & $\begin{array}{c}0.202 \\
(3.483)\end{array}$ \\
\hline 1905 and later & $\begin{array}{c}1.007 \\
(3.445)\end{array}$ & $\begin{array}{c}1.021 \\
(3.463)\end{array}$ & $\begin{array}{c}0.013 \\
(0.484)\end{array}$ & $\begin{array}{c}1.947 \\
(4.555)\end{array}$ & $\begin{array}{l}13.294 \\
(0.294)\end{array}$ & $\begin{array}{l}-0.056 \\
(-0.754)\end{array}$ \\
\hline Year & $\begin{array}{l}-0.020 \\
(-1.407)\end{array}$ & $\begin{array}{l}-0.014 \\
(-0.700)\end{array}$ & $\begin{array}{c}0.007 \\
(4.844)\end{array}$ & $\begin{array}{c}0.049 \\
(1.942)\end{array}$ & $\begin{array}{l}-3.357 \\
(-0.264)\end{array}$ & $\begin{array}{c}0.015 \\
(3.428)\end{array}$ \\
\hline $\begin{array}{l}\text { Firm costs per } \\
\text { member }\end{array}$ & - & - & $\begin{array}{c}0.004 \\
(5.876)\end{array}$ & - & - & $\begin{array}{c}0.001 \\
(0.268)\end{array}$ \\
\hline Constant & $\begin{array}{l}45.144 \\
(1.662)\end{array}$ & $\begin{array}{l}34.019 \\
(0.922)\end{array}$ & $\begin{array}{l}-11.568 \\
(-4.538)\end{array}$ & $\begin{array}{l}-81.197 \\
(-1.735)\end{array}$ & $\begin{array}{r}6,038.186 \\
(0.264)\end{array}$ & $\begin{array}{l}-26.988 \\
(-3.297)\end{array}$ \\
\hline Observations & 1307 & 1307 & 1307 & 934 & 934 & 934 \\
\hline $\begin{array}{l}\text { Number of } \\
\quad \text { Knappschaften }\end{array}$ & 48 & 48 & 48 & 30 & 30 & 30 \\
\hline Within $R^{2}$ & .119 & - & .576 & .125 & - & .211 \\
\hline Between $R^{2}$ & .014 & 一 & .006 & .009 & - & .107 \\
\hline Overall $R^{2}$ & .089 & - & .217 & .012 & - & .191 \\
\hline
\end{tabular}

Note: All models include Knappschaft-level fixed effects and controls for age structure.

imprecisely estimated. The best interpretation of the model is that these Knappschaften did not suffer moral hazard problems that manifested themselves in large numbers of sick days per worker. The results for the fast-growing KV are strikingly different. The IV estimate for Sick pay per day is essentially zero, but Firm's portion of costs led to more reported illness, a sure indicator that workers conditioned their behavior on who was paying.

In faster-growth Knappschaften, the size of the unit has two effects. A larger KV per se leads to slightly more Simulation, while larger individual production units leads to much more. The second elasticity is much larger (.047) than the former (.020) (see Table 7). If larger Knappschaften were able to capture scale economies to reduce the extent of Simulation, we would expect the first elasticity to be negative. Our 
coal-production proxy does not have the expected negative impact on sick days; greater production actually increases sickness, which is what one would expect if hard work leads to injuries.

The two mandates from the Reich each increased reported sickness for the dynamic KVs, but not the others. The 1887 law, which made all $\mathrm{KVs}$ adhere to the rules for the other sickness funds, increased reported sickness by about 7 percent (see Table 7). The 1905 changes had a slightly greater effect. In each case, there were two important changes: minimum sick pay increased and the period over which the miner could receive that pay increased.

We now turn to the "first-stage" regressions, which in this case tell us how Knappschaften determined the level of benefits they offered. The 1887 reform forced all associations to increase sick pay. Other impacts differ across the two groups. A larger KV offers more sick pay to members in a stagnant $\mathrm{KV}$, but not in a dynamic one. Both types offer more pay if the production units are larger. Both pay more when demand for coal is high.

The models reported in Tables 4A and 4B (and in Tables 1 through 3 and Tables 5A and 5B through 7 as well) include the Knappschaften in Silesia. These KV all supposedly introduced a rule that required all illnesses to be treated in hospital, although we unfortunately do not know when the KVs adopted these rules. We are not convinced that the rules were enforced in any consistent way; the proportion of all illnesses treated in hospital in Silesian institutions varies widely across KV and even over time within a single association. On average, the Silesian Knappschaften treated 57 percent of cases in hospital. The next largest proportion is in Bonn, with only 8 percent on average. But the distributions overlap. The Lower Silesian $\mathrm{KV}$, for example, often reported as few as 10 percent of all sick miners treated in hospital. This different policy in Silesian raises the question of whether these Knappschaften should be included with others in our models. If it were really true that they forced all sick miners to hospital, then we should not, as all the incentives for Simulation would be different. To examine this question, we reestimated the models separately for Silesian and nonSilesian Knappschaften. The results are slightly different, but none of our basic observations are overturned. So we continue to combine all the KV.

Ours is just one measure of moral hazard, but the results strongly suggest that contemporary commentators only partly understood the mechanisms underlying the growth of KV costs. The size effects contemporaries emphasized were definitely present: Knappschaften with 
TABLE 5A

(1)

(2)

All Knappschaften

\begin{tabular}{lcc} 
& \multicolumn{2}{c}{ All Knappschaften } \\
\cline { 2 - 3 } & FE & IV \\
\hline Sick pay per day & 0.074 & 0.821 \\
& $(2.514)$ & $(3.694)$ \\
Firm's portion of costs & 0.009 & -0.132 \\
KV members & $(0.088)$ & $(-1.051)$ \\
& -0.000 & 0.003 \\
Workers per unit & $(-0.527)$ & $(2.047)$ \\
Coal production & 0.084 & 0.034 \\
& $(5.288)$ & $(1.450)$ \\
1887 and later & -0.002 & -0.005 \\
& $(-1.267)$ & $(-2.789)$ \\
1905 and later & -0.024 & -0.188 \\
& $(-1.013)$ & $(-3.386)$ \\
Year & -0.097 & -0.077 \\
& $(-3.594)$ & $(-2.387)$ \\
Firm costs per member & -0.003 & -0.009 \\
Constant & $(-2.027)$ & $(-3.724)$ \\
& - & - \\
Observations & - & - \\
Number of Knappschaften & 5.843 & 17.452 \\
Within $R^{2}$ & $(2.246)$ & $(3.829)$ \\
Between $R^{2}$ & 1933 & 1933 \\
Overall $R^{2}$ & 64 & 64 \\
\hline
\end{tabular}

Note: All models include Knappschaft-level fixed effects and controls for age structure. The first-stage results for these models are not reported because they are nearly identical to those of the parallel model in Table 4A or 4B.

larger production units definitely experienced more sickness claims. But these effects are slight compared to the impact of more generous pay, especially when that sick pay is funded by the owners. And, to the extent our coal-production proxy is a good measure of the demand for miner labor, there is little evidence that the Simulation reflected disguised unemployment.

\section{Cases of Illness}

We now turn to the number of cases of reported illness. The number of sick cases approximates the number of times a worker paid the implicit cost of the waiting period (the Karenzzeit). Modeling sick cases thus 
TABLE 5B

DETERMINANTS OF THE NUMBER OF SICK CASES

(3) (4)

(5)

(6)

\begin{tabular}{|c|c|c|c|c|}
\hline & (3) & (4) & (5) & (6) \\
\hline & \multicolumn{2}{|c|}{ Dynamic Knappschaften } & \multicolumn{2}{|c|}{ Stagnant Knappschaften } \\
\hline & $\mathrm{FE}$ & IV & FE & IV \\
\hline Sick pay per day & $\begin{array}{c}0.073 \\
(2.193)\end{array}$ & $\begin{array}{c}0.078 \\
(0.378)\end{array}$ & $\begin{array}{c}0.127 \\
(2.034)\end{array}$ & $\begin{array}{l}4.546 \\
(2.837)\end{array}$ \\
\hline $\begin{array}{l}\text { Firm's portion of } \\
\text { costs }\end{array}$ & $\begin{array}{c}0.142 \\
(1.185)\end{array}$ & $\begin{array}{c}0.141 \\
(1.104)\end{array}$ & $\begin{array}{c}-0.259 \\
(-1.358)\end{array}$ & $\begin{array}{c}-0.981 \\
(-1.628)\end{array}$ \\
\hline KV members & $\begin{array}{c}0.000 \\
(0.069)\end{array}$ & $\begin{array}{c}0.000 \\
(0.067)\end{array}$ & $\begin{array}{l}-0.098 \\
(-5.085)\end{array}$ & $\begin{array}{l}-0.173 \\
(-2.820)\end{array}$ \\
\hline Workers per unit & $\begin{array}{c}0.090 \\
(5.555)\end{array}$ & $\begin{array}{c}0.089 \\
(4.520)\end{array}$ & $\begin{array}{c}0.222 \\
(2.928)\end{array}$ & $\begin{array}{c}0.055 \\
(0.244)\end{array}$ \\
\hline Coal production & $\begin{array}{l}-0.002 \\
(-1.110)\end{array}$ & $\begin{array}{l}-0.002 \\
(-0.806)\end{array}$ & $\begin{array}{l}-0.003 \\
(-0.978)\end{array}$ & $\begin{array}{c}0.006 \\
(0.661)\end{array}$ \\
\hline 1887 and later & $\begin{array}{l}-0.013 \\
(-0.436)\end{array}$ & $\begin{array}{l}-0.014 \\
(-0.258)\end{array}$ & $\begin{array}{l}-0.042 \\
(-1.060)\end{array}$ & $\begin{array}{l}-0.906 \\
(-2.737)\end{array}$ \\
\hline 1905 and later & $\begin{array}{l}-0.170 \\
(-5.050)\end{array}$ & $\begin{array}{l}-0.170 \\
(-5.044)\end{array}$ & $\begin{array}{l}-0.020 \\
(-0.424)\end{array}$ & $\begin{array}{c}0.125 \\
(0.889)\end{array}$ \\
\hline Year & $\begin{array}{l}-0.003 \\
(-1.745)\end{array}$ & $\begin{array}{l}-0.003 \\
(-1.331)\end{array}$ & $\begin{array}{c}-0.002 \\
(-0.889)\end{array}$ & $\begin{array}{c}-0.066 \\
(-2.722)\end{array}$ \\
\hline $\begin{array}{l}\text { Firm costs per } \\
\text { member }\end{array}$ & - & - & - & - \\
\hline Constant & $\begin{array}{c}5.706 \\
(1.866)\end{array}$ & $\begin{array}{c}5.771 \\
(1.462)\end{array}$ & $\begin{array}{c}5.647 \\
(1.087)\end{array}$ & $\begin{array}{c}121.241 \\
(2.742)\end{array}$ \\
\hline Observations & 1201 & 1201 & 732 & 732 \\
\hline Number of Knappschaften & 43 & 43 & 21 & 21 \\
\hline Within $R^{2}$ & .079 & - & .102 & - \\
\hline Between $R^{2}$ & 0 & - & .014 & - \\
\hline Overall $R^{2}$ & .027 & - & .015 & - \\
\hline
\end{tabular}

Note: All models include Knappschaft-level fixed effects and controls for age structure. The first-stage results for these models are not reported because they are nearly identical to those of the parallel model in Table 4A or 4B.

allows us to separate false claims of illness from false claims about the length of illness (Verschleppung). This information is unfortunately only available for Prussian KV. Tables 5A and 5B report models strictly parallel to those in Tables $4 \mathrm{~A}$ and $4 \mathrm{~B}$, but this time the dependent variable is the number of cases of illness per Knappschaft member. ${ }^{54}$ In the IV results for all KV and for the dynamic associations, the signs on Sick pay per day, Firm's portion of costs, and the two size-of-association variables are as expected, and similar to the results in Tables 4A and 4B (although some effects are only marginally significant). ${ }^{55}$ But we now see another

\footnotetext{
${ }^{54}$ The source does not make clear whether the number of cases includes instances where a worker began but did not complete the Karenzzeit.

${ }^{55}$ The first-stage results here differ from the early model because these data are only available for the Prussian KV.
} 


\begin{tabular}{|c|c|c|}
\hline & All $K$ & chaften \\
\hline & $\mathrm{FE}$ & IV \\
\hline Sick pay per day & $\begin{array}{c}-4.432 \\
(-7.337)\end{array}$ & $\begin{array}{c}-7.172 \\
(-1.811)\end{array}$ \\
\hline Firm's portion of costs & $\begin{array}{c}5.385 \\
(2.563)\end{array}$ & $\begin{array}{c}5.902 \\
(2.637)\end{array}$ \\
\hline KV members & $\begin{array}{c}0.031 \\
(1.801)\end{array}$ & $\begin{array}{c}0.019 \\
(0.795)\end{array}$ \\
\hline Workers per unit & $\begin{array}{c}-0.698 \\
(-2.133)\end{array}$ & $\begin{array}{l}-0.515 \\
(-1.226)\end{array}$ \\
\hline Coal production & $\begin{array}{c}0.051 \\
(1.983)\end{array}$ & $\begin{array}{c}0.063 \\
(2.030)\end{array}$ \\
\hline 1887 and later & $\begin{array}{c}0.713 \\
(1.460)\end{array}$ & $\begin{array}{c}1.313 \\
(1.329)\end{array}$ \\
\hline 1905 and later & $\begin{array}{c}5.484 \\
(9.819)\end{array}$ & $\begin{array}{c}5.407 \\
(9.451)\end{array}$ \\
\hline Year & $\begin{array}{c}0.113 \\
(3.929)\end{array}$ & $\begin{array}{c}0.137 \\
(3.060)\end{array}$ \\
\hline Firm costs per member & - & - \\
\hline Constant & $\begin{array}{r}-196.527 \\
(-3.667)\end{array}$ & $\begin{array}{r}-239.124 \\
(-2.942)\end{array}$ \\
\hline Observations & 1933 & 1933 \\
\hline Number of Knappschaften & 64 & 64 \\
\hline Within $R^{2}$ & .183 & \\
\hline Between $R^{2}$ & .003 & - \\
\hline Overall $R^{2}$ & .086 & - \\
\hline
\end{tabular}

Note: All models include Knappschaft-level fixed effects and controls for age structure. The first-stage results for these models are not reported because they are nearly identical to those of the parallel model in Table 4A or 4B.

impact of the 1887 and 1905 reforms. In both cases, the reported number of cases of sickness declines. In the absence of any change in Knappschaft practice, we would expect the Reich measures to increase reported sickness. Clearly, this reflects the Knappschaften trying to control costs; if the number of illnesses had not declined, the greater sick pay could have overwhelmed the fund.

\section{Length of Illness}

We turn now to the mean length of reported illness, which again is only available for Prussian Knappschaften. This dependent variable differs from the one used in Tables 4A and 4B because we in effect condition on whether a member was ill at all. Tables 6A and 6B report 
TABLE 6B DETERMINANTS OF LENGTHS OF ILLNESSES

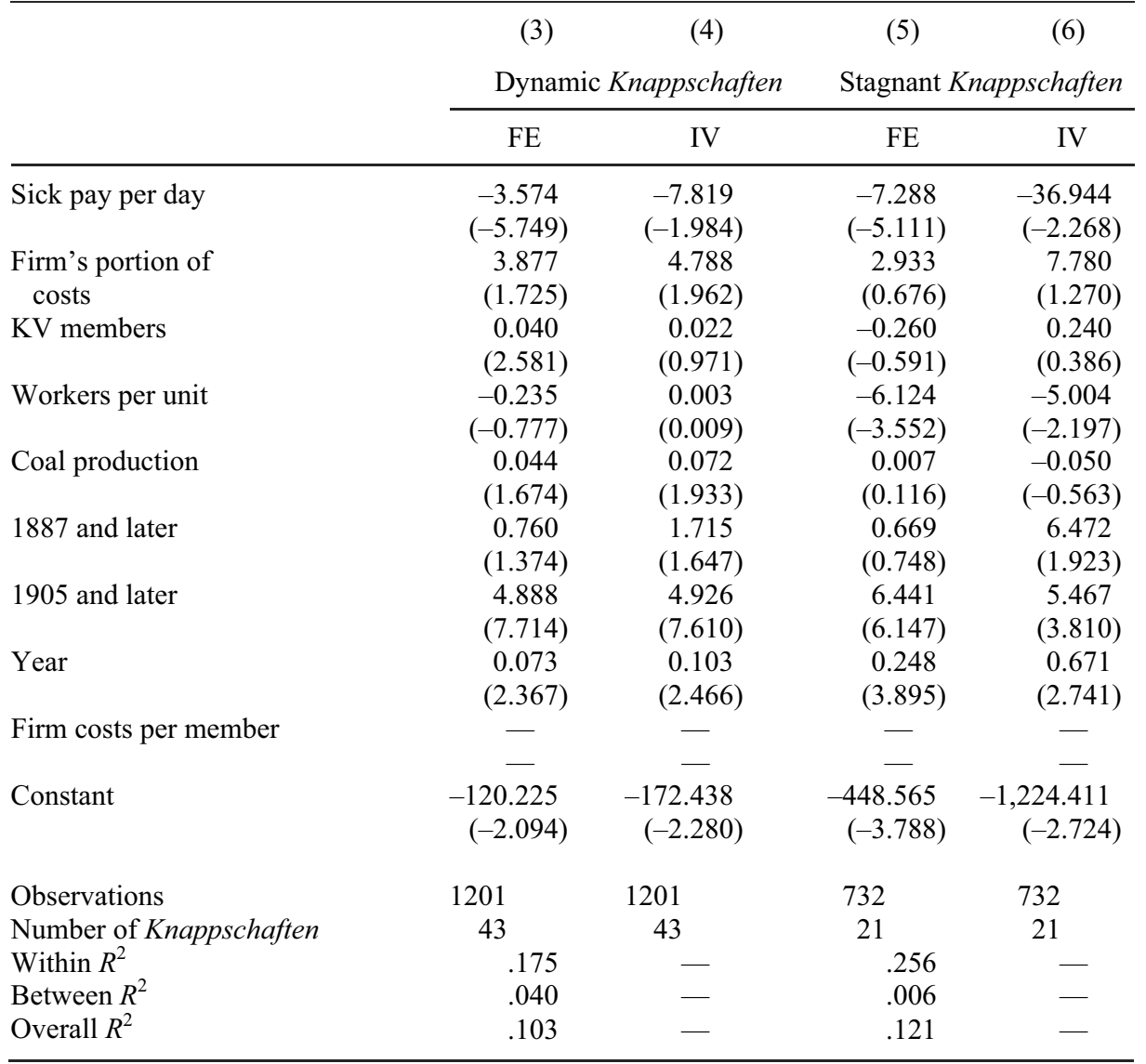

Note: All models include Knappschaft-level fixed effects and controls for age structure. The first-stage results for these models are not reported because they are nearly identical to those of the parallel model in Table 4A or 4B.

regressions parallel to those in Tables 4A and 4B and Tables 5A and 5B. The results here contain some surprises. Increased sick pay shortens reported illnesses, the model claims. The firm's portion of total costs has a large, positive impact on the length of illness, save for stagnant Knappschaften. The 1905 reform increased the duration of illnesses, but the effect is small if statistically significant. Tables 6A and 6B illustrate the multiple tools available to Knappschaften that worried about Simulation. The 1905 reform, for example, doubled the maximum period for sick benefit. This would seem an invitation to malingering, but the actual increase is rather small. This result presumably reflects the KV's fears about what could happen after 1905, and their efforts to combat the problem. 
TABLE 7

SUMMARY OF MORAL HAZARD EFFECTS

\begin{tabular}{lccc}
\hline \hline & $\begin{array}{c}\text { Sick Days per } \\
\text { Member }\end{array}$ & $\begin{array}{c}\text { Sick Cases per } \\
\text { KV Member }\end{array}$ & $\begin{array}{c}\text { Sick Days per } \\
\text { Case of Illness }\end{array}$ \\
\hline Sick pay per day & -.276 & .109 & -.507 \\
Firm's portion of costs & .213 & .094 & .148 \\
KV members & .020 & .001 & .016 \\
Workers per unit & .047 & .056 & 0 \\
Coal production & .055 & 0.036 & .077 \\
1887 and later & .066 & -.009 & .054 \\
1905 and later & .085 & -.016 & .022
\end{tabular}

Note: Figures reported are elasticities evaluated at the mean. Figures in italics are associated with a $t$-ratio greater than 1.9.

Source: IV regressions for "dynamic" KV reported in Tables 4-7.

Table 7 reports elasticities from these last three models to summarize the determinants of our several measures of Simulation. There is no reason these impacts should all be similar; for example, when the Reich forced Knappschaften to extend more generous benefits, one might well expect that the KV would try to reduce Simulation and thus achieve a reduction in the number of sick cases, leaving only the truly sick and thus long average periods of illness. This outcome would have an ambiguous effect on overall sick days per member. In any case, there are some overall generalizations to draw from our models. First, firms that shouldered a greater share of the KV's costs experienced higher levels of sickness. The same goes for Knappschaften with relatively large production units. That this effect is zero in the last model (of sick days per case) suggests that the information and informal sanctions available to workers in smaller enterprises only worked to discourage shorter periods of malingering. Finally, the 1887 and 1905 reforms produced precisely what we would expect if there was significant malingering beforehand: when forced to pay greater benefits for a longer period, the Knappschaften found ways to reduce the number of cases of illness at the expense of longer average illnesses. The later, of course, is not really a cost, if it meant the Knappschaften were now concentrating resources on the truly ill. 


\section{CONCLUSIONS}

The Knappschaften grew out of medieval miners' efforts to insure themselves against the economic consequences of their dangerous jobs. By the late nineteenth century, the KV were state-sanctioned, self-run sickness funds. Membership was compulsory for workers in covered industries, and the individual Knappschaften had considerable autonomy over important policy decisions. Bismarck's social insurance legislation used them as the model for similar funds in other industries, and as such they remain the model for German illness and accident insurance today.

Late-nineteenth-century observers noted that Knappschaften experienced strong growth in the number of days their members claimed to be sick. Contemporaries blamed this development on Simulation, or feigning illness, and thought it reflected changes in the miners' social status and the deterioration of social ties among $\mathrm{KV}$ members brought about by increases in the size and territory of individual associations. This article uses aggregate data on the Knappschaften to test these claims. We find that there was indeed considerable Simulation, as suggested by huge variations in the incidence of rheumatism and its strong correlation with proxies for the attractiveness of feigning illness. Turning to the determinants of reported sickness itself, we find that in growing Knappschaften, miners were attuned to both the generosity of sick pay and the portion of the KV's costs paid for by owners. Contemporaries were also correct that as the units in which miners worked grew larger, apparent incidents of illness became more common. We find little evidence for a potential offsetting effect; larger Knappschaften apparently did not find ways to use their size to achieve efficiencies in monitoring, medical treatment, or both. Finally, we find that Simulation in the many shrinking Knappschaften took a different form; we know it was considerable, but it apparently was not strongly correlated with observable $\mathrm{KV}$ characteristics. Membership in a dying organization seemed enough to bring out the strongest moral hazard problems.

The simple theoretical model we used to organize thought implies that the Knappschaften faced a dilemma. Health status was often unobservable. The Knappschaft could try to rely on the information miners had about each other, but this approach became less useful as the institutions grew in size. Even if the KV had resisted pressure to merge, remaining small entailed forgoing economies of scale in the treatment of actuarial risk. Given that their social basis was increasingly undermined by their scale, the Knappschaften had to turn to "control" 
methods to reduce Simulation. Measures such as forced hospitalization, required visits by doctors and other employees, etc., might help to reduce information problems in the short run, but worked to undermine any sense that the Knappschaft was a mutual organization and not an insurance company. Once the Knappschaften acted like an insurance company, it risked creating a vicious circle where sharper controls undermined the worker solidarity that restrained many from abusing the system.

\section{REFERENCES}

Ashton, T. S. "The Relation Between Unemployment and Sickness." The Economic Journal 26, no. 103 (1916): 396-400.

Banken, Ralf. Die Industrialisierung der Saarregion, 1815-1914. Vol. 2: Take-OffPhase und Industrialisierung. Stuttgart: Franz Steiner, 2000.

Besley, Timothy J., Stephen C. Coate, and Timothy W. Guinnane. "Incentives, Information, and Welfare: England's New Poor Law and the Workhouse Test." In History Matters: Essays on Economic Growth, Technology, and Demographic Change, edited by Timothy W. Guinnane, William A. Sundstrom, and Warren C. Whatley, 245-70. Stanford, CA: Stanford University Press, 2003.

Bluma, Lars, Stefan Schulz, and Jochen Streb. "Prinzipal-Agenten-Probleme in der knappschaftlichen Krankenversicherung: Die Bekämfung des "Simulantentums" durch Anreize und Kontrolle. Vierteljahrschrift für Sozial- und Wirtschaftsgeschichte 97, no. 3 (2010): 310-34.

Bound, John, David A. Jaeger, and Regina M. Baker. "Problems with Instrumental Variables Estimation When the Correlation Between the Instruments and the Endogenous Explanatory Variable is Weak." JASA 90, no. 430 (1995): 443-50.

Bry, Gerhard. Wages in Germany, 1871-1945. Princeton, NJ: Princeton University Press, 1960.

Bülow, Wilhelm. Das Knappschaftswesen im Ruhrkohlenbezirk bis zum allgemeinen preußischen Berggesetz vom 24. Juni 1865. Ph.D. Diss., Tübingen, 1905.

Elsholz, Ulrich. Die Entwicklung des sächsischen Knappschaftswesens. Ph.D. Diss., Jena, 1910.

Emery, J. C. Herbert. "Risky Business? Nonactuarial Pricing Practices and the Financial Viability of Fraternal Sickness Insurers." Explorations in Economic History 33, no. 2 (1996): 195-226.

Gilbert, Bentley. "The Decay of Nineteenth-Century Provident Institutions and the Coming of the Old Age Pensions in Great Britain." Economic History Review 17, no. 3 (1965): 551-63.

Gottlieb, Daniel. "Asymmetric Information in Late Nineteenth-Century Cooperative Insurance Societies.” Explorations in Economic History 44, no. 2 (2007): 270 92.

Guinnane, Timothy W. "Cooperatives as Information Machines: German Rural Credit Cooperatives, 1883-1914." The Journal of Economic History 61, no. 2 (2001): 366-89.

Guinnane, Timothy W., and Jochen Streb. "Moral Hazard in a Mutual Health-Insurance System: German Knappschaften, 1867-1914.” Ruhr Economic Papers No. 163, SSRN No. 1484753, 2010. 


\section{Moral Hazard in a Mutual Health Insurance System 103}

Hennock, E. Peter. The Origin of the Welfare State in England and Germany, 1850 1914: Social Policies Compared. New York: Cambridge University Press, 2007.

Hentschel, Volker. Geschichte der deutschen Sozialpolitik, 1880-1980. Frankfurt/Main: Suhrkamp, 1983.

Imbusch, Heinrich. Das deutsche Knappschaftswesen: eine Darstellung seiner Entwicklung und seines heutigen Standes, unter besonder Berüsichtigung des Knappsrechtes und des Wirkens der Knappschaftsvereine in der Praxis. Köln: Christlicher Gewerkschafts-Verlag, 1910.

Jopp, Tobias A. "Ein risikoreiches Geschäft? Internes und externes Wachstum als risikopolitische Instrumente im preußischen Knappschaftswesen, 1854-1923.” In Berufliches Risiko und Soziale Sicherheit, edited by Christoph Bartels, 189-224. Bochum: Deutsches Bergbaumuseum, 2010a.

. "The Welfare State Evolves: German Knappschaften, 1854-1923." University of Hohenheim FZID Discussion Papers 16, $2010 \mathrm{~b}$.

Khoudhour-Castéras, David. "Welfare State and Labor Mobility: The Impact of Bismarck's Social Legislation on German Emigration Before World War I." The Journal of Economic History 68, no. 1 (2008): 211-34.

Klein, Jennifer. For All These Rights: Business, Labor, and the Shaping of America's Public-Private Welfare State. Princeton, NJ: Princeton University Press, 2003.

Köhne, August. Die deutschen Knappschaftsvereine, ihre Einrichtung und ihre Bedeutung. Hannover: Helwingsche Verlagsbuchhandlung, 1915.

Lauf, Ulrich. Die Krankenhäuser der deutschen Knappschaftsvereine im 19. und 20. Jahrhundert. Bochum: Deutsche Rentenversicherung Knappschaft-Bahn-See, 2005.

"Die deutschen Knappschaftsvereine (1854-1923). Ein altes Sozialsystem im Rückblick. Der Anschnitt 58 (2006): 264-94.

Menzel, Elmar. Bergbau-Medizin einst und jetzt. Entwicklung des bergmännischen Gesundheitswesens unter Einschluss der Kranken- und Unfallversicherung Berlin: Erich Schmidt Verlag, 1989.

Murray, John. "Worker Absenteeism Under Voluntary and Compulsory Sickness Insurance: Continental Europe, 1885-1908." Research in Economic History 23 (2005): 177-207.

Origins of American Health Insurance: A History of Industrial Sickness Funds. New Haven, CT: Yale University Press, 2007.

Riley, James C. Sick, Not Dead: The Health of British Workingmen During the Mortality Decline. Baltimore, MD: The Johns Hopkins University Press, 1997.

Schlockow, Isak. Die Gesundheispflege und medizinische Statistik beim Preußischen Bergbau. Heymann, Berlin, 1881.

Simons, Peter. Das deutsche Knappschaftswesen. Mainz: Diemer, 1895.

Tampke, Jürgen. "Bismarcks Sozialgesetzgebung: Ein wirklicher Durchbruch?" In Die Entstehung des Wohlfahrtsstaates in Großbritannien und Deutschland, 1850-1950, edited by Wolfgang J. Mommsen, 79-91. Stuttgart: Klett-Cotta, 1982.

Wagner-Braun, Margarete. Zur Bedeutung berufsständischer Krankenkassen innerhalb der privaten Krankenversicherung in Deutschland bis zum Zweiten Weltkrieg. Beiträge zur Wirtschafts- und Sozialgeschichte vol. 95. Stuttgart: Franz Steiner Verlag, 2002.

Whiteside, Noel. "Counting the Cost: Sickness and Disability Among Working People in an Era of Industrial Recession, 1920-1939." Economic History Review 40, no. 2 (1987): 228-46. 
Wilkinson, John F. “Friendly Society Finance.” Economic Journal 2, no. 8 (1892):72127.

Wirtz, August. Entwicklung und Organisation des Knappschaftswesens im Ruhrkohlenbezirk. Ph.D. Diss., Heidelberg, 1911. 